\title{
Discussions of Effect A1 and A2 Milk Beta-Casein Gene on Health
}

\author{
Ahmet Fatih Demirel and Bahattin ÇAK* \\ Department of Veterinary Medicine, Turkey \\ *Corresponding author: Bahattin ÇAK, Department of Faculty of Veterinary Medicine, Turkey
}

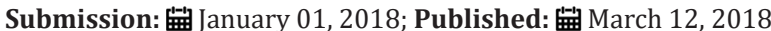

\begin{abstract}
Scientists in developed countries have still discuss the situation of milk A1 and A2. The controversy is that one group of scientists claim of A1 type a cause of many health problems in human whereas other groups report beneficial effects of A1 type and declare both types of milk safe for children and adults. The biological function of milk is to supply nutrition and immunological protection to the young mammal. Milk should be consumed for adequate and balanced nutrition. Economically the important milk constituents include: fat, protein, Solid Not Fat (SNF), lactose and ash. More than $95 \%$ of the cow milk proteins are constituted by caseins and whey proteins. Among the caseins, beta-casein is the second most abundant protein and has excellent nutritional balance of amino acids. The composition of beta-casein of milk and milk products has become an important economic trait of dairy animal. Beta-CasoMorphin-7 (BCM7) is suggested to be a risk factor for human health bas it can potentially affect numerous opioid receptors in the nervous, endocrine and immune system. The aim of this review was to evaluate discussions of effect A1 and A2 milk Beta-casein gene on health.
\end{abstract}

Keywords: Beta-casein A1; Beta-casein A2; BCM-7; Cow milk

Abbreviations: BCM-7: Beta-CasoMorphin-7; CSN2: Beta-Casein; ASD: Autistic Spectral Disorder; SIDS: Sudden Infant Death Syndrome

\section{Introduction}

Cow's milk constitutes a large part of nutrition in the developing world and a liter contains an average of 32g of protein [1].

Beta-casein A1 protein variant might be one of the risk factors in the etiology of human disorders like diabetes and ischemic heart disease. However, from the practical perspective selecting for the A2 allele in dairy cattle requires knowledge of whether the A1/A2 polymorphism is associated with breeding values for production traits [2].

\section{Composition of Milk}

Milk define as a whitish liquid containing milk proteins, fats, lactose, and various vitamins and minerals, produced by the mammary glands of all adult female mammals after childbirth and serves as food for their young [3]. Milk is a considerable resource of products whose composition varies. Four components are dominant in quantitative terms: water, fat, protein and lactose; while the minor components are minerals, enzymes, vitamins, and dissolved gases. It satisfies the demand of the consumer who seeks more and more innovative products with consistent quality. The dairy industry needs to utilize all the riches of this raw material, which is both simple in appearance and complex in composition. In general, goat milk compared to cow milk is less rich in lactose, fat and proteins, but have similar mineral content [4].

\section{Milk Protein}

Bovine milk contains roughly $3.5 \%$ of protein. The natural functions of milk proteins is to supply young mammals with the essential amino acids required for the development of muscular and other protein-containing tissues [5]. In addition, milk proteins also play a very important role in dairy and food products, e.g. during processing, including undesirable behavior such as fouling on heated surfaces, and gelling inside processing equipment [6].

Proteins are large organic compounds playing a central role in the structure of all living organisms. Besides their structural and functional roles proteins are also a fundamental component of animal and human diets providing a source of energy, nitrogen and essential amino acids [7]. Among milk proteins the major groups are caseins (beta-lactoglobulin) and whey (alpha-lactalbumin) proteins $[8,9]$

\section{Caseins}

Caseins are phosphoproteins containing approximately 80\% of the total protein content of milk $[6,10,11]$. Casein is made up of many components, and the main types are alpha s1-casein, alpha s2-casein, beta-casein, and kappa-casein [12] as defined and validated by analysis of DNA sequences [6]. 
Bovine milk contains four main casein groups, namely, alpha s1-, alpha s2-, beta- and kappa-casein accounting for 38.10,36, and $13 \%$ of total proteins in milk, respectively $[9,11,13$,$] .$

\section{Beta-Casein Gene?}

Beta-casein (CSN2) is the most polymorphic milk protein gene with 13 variants viz. A1, A2, A3, B, C, D, E, F, H1, H2, I, G and mostly observed forms of beta-casein in dairy cattle breeds are A1 and A2 [13,14]. There are 13 genetic variants of beta-casein: A1, A2, A3, A4 B, C, D, E, F, H1, H2, I, G. The most common forms are A1 and $A 2$, while $B$ is less common, and $A 3$ and $C$ are rare [15]. The composition of beta-casein of milk and milk products has become an important economic trait of dairy animal [16].

\section{History of $\mathrm{A} 1$ and $\mathrm{A} 2$ beta-casein}

Interest in the distinction between $\mathrm{A} 1$ and $\mathrm{A} 2$ beta-casein proteins began in the early 1990s [17] via epidemiological research and animal studies initially conducted by scientists in New Zealand, who found correlations between the prevalence of milk with A1 beta-casein proteins in some countries and the prevalence of various chronic diseases. Investigations on this subject continue to raise interest among the media, the science community and entrepreneurs. [18].

\section{Difference between A1 and A2 beta-casein}

$\mathrm{A} 1$ and $\mathrm{A} 2$ variants are differentiated by the change of one nucleotide in the position 67 of the chain (A1 histidine and A2 proline). Initial studies have indicated that the entire bovine population contained only the A2 allele, and A1 allele was created from a mutation [19]. The nucleotide sequence change in 67th amino acid position of the beta-casein reading frame, from CCT to CAT, causes substitution of proline (A2) by histidine $(\mathrm{A} 1, \mathrm{~B})$ in the amino-acid sequence (Figure 1 ). This might cause a change in the secondary conformation of the protein structure and affect the physical properties of casein micelle and vulnerability to enzymatic digestion. During this enzymatic process, beta-casein opioid peptide beta-casomorphin-7 (BCM 7) is released exclusively from $A 1$ and $B$ variants $[20,21]$.

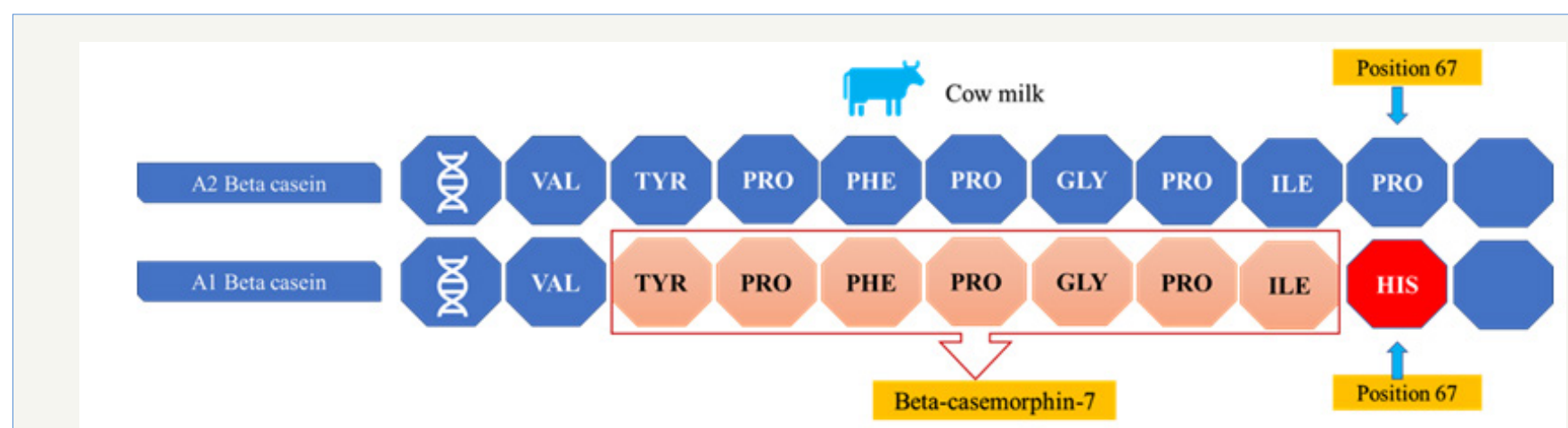

Figure 1: Different between A1 and A2 variants and formation of beta-casemorphin-7.

A2 milk is cow's milk that contains only the A2 variant of betacasein protein. According to the literature, more than 10,000 years ago, and before they were domesticated, cows produced only the A2 beta-casein protein and not the A1 beta-casein protein. However, some 8,000 years ago a natural single-gene mutation occurred in Holsteins, resulting in production of the $\mathrm{A} 1$ beta-casein protein in this breed. This mutation in the beta-casein gene led to 12 genetic variants, of which $\mathrm{A} 1$ and $\mathrm{A} 2$ are most common. The mutation was passed on to many other breeds, principally because Holsteins are used to genetically improve the production of other breeds. Slowly, the A1 beta-casein variant became dominant in milk. While dairy herds in much of Asia, Africa, and part of Southern Europe remain naturally high in cows producing A2 milk, the A1 version of the protein is common among cattle in the Western world [22]. Summary of beta-casein allele frequency distribution in selected Western cattle breeds has been presented in (Table 1).

Table 1: Summary of beta-casein allele frequency distribution in selected Western cattle breeds (EFSA 2009).

\begin{tabular}{|c|c|c|c|c|c|c|}
\hline Breed & No. Animals & P-Casein Allele Frequency & & Reference \\
\hline & & A1 & A2 & B & Other & Caldwell et al. 1971 \\
\hline Angus & 77 (USA) & 0.95 & & 0.05 & Kiddy et al. 1966 \\
\hline Ayrshire & 45 (USA) & 0.72 & 0.28 & & Aschaffenburg 1968 \\
\hline Ayrshire & 29 (UK) & 0.6 & 0.4 & & 24 Kim \\
\hline Ayrshire & ?(Canada) & 0.6 & & & Winkelman and \\
\hline 1994 & & & 0.527 & & Wickham 1997 \\
\hline Ayrshire & 37 (N. Zealand) & 0.432 & 0.49 & 0.001 & & Ikonen et al. 1996 \\
\hline Ayrshire & 20,990 (Finland) & 0.509 & 0.5 & & Lien et al. 1999 \\
\hline Ayrshire & 46 (Finland) & 0.5 & & 0.03 & & Pupkova1980 \\
\hline Black Pied & 140 (Estonia) & $0.97 *$ & &
\end{tabular}




\begin{tabular}{|c|c|c|c|c|c|c|}
\hline Braham & 59 (USA) & $0.99 *$ & & 0.01 & & Caldwell et al. 1971 \\
\hline Brown Italian & 298 (Italy) & 0.11 & 0.69 & 0.18 & 0.02 & Boettcher et al.2004 \\
\hline Brown Swiss & ?(Canada) & 0.32 & 0.52 & 0.16 & & 24 Kim 1994 \\
\hline Brown Swiss & 22 (USA) & 0.14 & 0.66 & 0.18 & C: 0.02 & Kiddy et al. 1966 \\
\hline Brown Swiss & 50 (USA) & 0.18 & 0.66 & 0.16 & & $\begin{array}{l}\text { Van Eenennaam, } \\
\text { Medrano } 1991\end{array}$ \\
\hline Canadienne & $?($ Canada) & 0.58 & 0.34 & 0.08 & & 24Kim 1994 \\
\hline Dutch-Fr & 10151 (Holland) & 0.766 & 0.147 & 0.014 & B:0.073 & $\begin{array}{l}\text { Bovenhuis van } \\
\text { Arendonk } 1991\end{array}$ \\
\hline Finncattle & 31 (Finland) & 0.274 & 0.71 & 0.016 & & Lien et al. 1999 \\
\hline \multicolumn{7}{|l|}{$(\mathrm{EFC})$} \\
\hline Finncattle & 26 (Finland) & 0.385 & 0.615 & & & Lien et al. 1999 \\
\hline \multicolumn{7}{|l|}{$(\mathrm{NFC})$} \\
\hline Finncattle & 41 (Finland) & 0.293 & 0.671 & 0.037 & & Lien et al. 1999 \\
\hline \multicolumn{7}{|l|}{ (WFC) } \\
\hline Friesian(F) & 3761 (N. Zealand) & 0.465 & 0.51 & & & $\begin{array}{c}\text { Winkelman, Wickham } \\
1997\end{array}$ \\
\hline Friesian(Fr)נ) & 347 (Italy) & 0.38 & 0.55 & 0.07 & & Boettcher et al.2004 \\
\hline Grey & 120 (Hungary) & 0.23 & 0.76 & 0.01 & & Baranyi et al. 1993 \\
\hline Guernsey & 196 (USA) & 0.01 & 0.98 & 0.02 & & Aschaffenburg, 1963 \\
\hline Guernsey & 40 (USA) & & 0.96 & & C:0.04 & $\begin{array}{l}\text { Van Eenennaam } \\
\text {,Medrano, } 1991\end{array}$ \\
\hline Hereford & 48 (USA) & $0.75^{*}$ & & 0.25 & & Caldwell et al. 1971 \\
\hline Holstein & 260 (Australia) & 0.63 & 0.35 & 0.02 & & McLean et al. 1984 \\
\hline Holstein & 1383 (Italy) & 0.58 & 0.4 & 0.02 & & Aleandri et al. 1997 \\
\hline Holstein & 1152 (USA) & 0.43 & 0.55 & 0.02 & & $\begin{array}{l}\text { Van Eenennaam and } \\
\text { Medrano, } 1991\end{array}$ \\
\hline Holstein-Fr & 85 (UK) & 0.66 & 0.24 & 0.06 & A3:0.04 & $\begin{array}{c}\text { Aschaffenburg et al. } \\
1968\end{array}$ \\
\hline Holstein-Fr & 87 (Germany) & & 0.96 & 0.04 & & $\begin{array}{l}\text { Aschaffenburg et al. } \\
1968\end{array}$ \\
\hline Holstein-Fr & 6460(Canada) & 0.54 & 0.44 & 0.01 & A3:0.01 & Hines et al. 1977 \\
\hline Holstein-Fr & 6575 (USA) & 0.42 & 0.53 & 0.02 & A3:0.03 & Hines et al.1977 \\
\hline Holstein-Fr & 260 (USA) & 0.624 & 0.347 & 0.025 & A3:0.004 & McLean et al. 1984 \\
\hline
\end{tabular}

In general, milks from Guernsey, Jersey, Asian herds, human milk, and others (sheep, goat, donkeys, yaks, camel, buffalo etc.) contain mostly A2 beta-casein. Milks from Holstein Friesian contain mostly A1 beta-casein. The Holstein breed (the most common dairy cow breed in Australia, Northern Europe, and the United States)

comprises A1 and A2 forms of beta-caseins in approximately equal amounts. More than 50 percent of the Jersey breed carries the A2 beta-casein variant, but with considerable variation among the herd, and more than 90 percent of the Guernsey breed carries the A2 beta-casein variant [22] (Table 2).

Table 2: The beta-casein A genetic variants were not distinguished into A1, A2 and A3 variants? number of animals in study not given; EFC - Eastern Finncattle; NFC - Northern Finncattle; WFC - Western Finncattle.

\begin{tabular}{|c|c|c|c|c|c|c|}
\hline Breed & No. Animals & P-Casein Allele Frequency & & & Reference \\
\hline & & A1 & A2 & B & Other & A3:0.004 \\
\hline Holstein-Fr & 920 (Canada) & 0.363 & 0.632 & 0.001 & 0.03 & 0.25 \\
\hline Holstein-Fr & 696 (Ireland) & 0.72 & 0.523 & 0.047 & Lien et al. 1999 1995 \\
\hline Holstein-Fr & 43 (Finland) & 0.43 & 0.598 & & Kaminski et al. 2007 \\
\hline Holstein-Fr & 143 (Poland) & 0.402 & 0.674 & & Lien et al. 1999 \\
\hline Icelandic & 44 (Iceland) & 0.326 & 0.49 & 0.29 & & Kiddy et al. 1966 \\
\hline Jersey & 37 (USA) & 0.22 & & & & \\
\hline
\end{tabular}




\begin{tabular}{|c|c|c|c|c|c|c|}
\hline Jersey & 47 (UK) & 0.09 & 0.63 & 0.28 & & Aschaffenburg 1968 \\
\hline Jersey & 308 (Australia) & 0.07 & 0.57 & 0.36 & & McLean et al. 1984 \\
\hline Jersey & 157 (Denmark) & 0.07 & 0.58 & 0.35 & & Bech, Kristiansen 1990 \\
\hline Jersey & 172(USA) & 0.17 & 0.5 & 0.33 & & $\begin{array}{l}\text { Van Eenennaam, } \\
\text { Medrano } 1991\end{array}$ \\
\hline Jersey & ?(Canada) & 0.19 & 0.5 & 0.31 & & Ng-Kwai-Hang Kim 1994 \\
\hline Jersey & 116 (Ireland) & 0.3 & 0.41 & 0.28 & A3 : 0.01 & O’ Hara 1995 \\
\hline Jersey & $\begin{array}{l}1328(\mathrm{~N} . \\
\text { Zealand) }\end{array}$ & 0.123 & 0.591 & & & $\begin{array}{c}\text { Winkelman, Wickham } \\
1997\end{array}$ \\
\hline Kerry & 123 (Ireland) & $1.00^{*}$ & & & & Murphy Downey1969 \\
\hline Kerry & 41 (Ireland) & 0.24 & 0.76 & & & O' Hara, 1995 \\
\hline Normande & 155 (France) & 0.21 & 0.32 & 0.45 & A3: 0.02 & Aschaffenburg 1968 \\
\hline Norwegian & 38(Norway) & 0.513 & 0.487 & & & Lien et al. 1999 \\
\hline Red Danish & 169 (Denmark) & 0.71 & 0.23 & 0.06 & & Bech, Kristiansen, 1990 \\
\hline Shorthorn & 40 (USA) & 0.49 & 0.49 & 0.02 & & $\begin{array}{l}\text { Van Eenennaam } \\
\text { Medrano } 1991\end{array}$ \\
\hline Simmental & 2626 (Denmark) & 0.231 & 0.673 & 0.082 & C : 0.013 & Baranyi et al. 1993 \\
\hline Simmental & 621 (Croatia) & 0.19 & 0.63 & 0.15 & & Curik et al. 1997 \\
\hline SLB & 43(Sweden) & 0.407 & 0.593 & & & Lien et al.1999 \\
\hline SLB & 42 (Sweden) & 0.34 & 0.6 & 0.06 & & Hallén et al. 2008 \\
\hline Spotted & 101 (Hungary) & 0.21 & 0.715 & 0.06 & $C: 0.015$ & Baranyi et al. 1993 \\
\hline SRB & 394(Sweden) & 0.46 & 0.531 & 0.008 & & Lunden et al.1997 \\
\hline SRB & 39(Sweden) & 0.397 & 0.603 & & & Lien et al. 1999 \\
\hline SRBH & 39 (Sweden) & 0.44 & 0.55 & 0.01 & & Hallén et al. 2008 \\
\hline SRBL & 35 (Sweden) & 0.36 & 0.63 & 0.01 & & Hallén et al. 2008 \\
\hline White Danish & 223 (Denmark) & 0.55 & 0.39 & 0.03 & A3 : 0.03 & Bech ,Kristiansen, 1990 \\
\hline
\end{tabular}

Recently, a relationship between disease risk and consumption of a specific bovine beta-casein fraction with either A1 or A2 genetic variants has been identified. BCM7 is suggested to be associated as a risk factor for human health hazards as it can potentially affect numerous opioid receptors in the nervous, endocrine and immune system [23].

\section{Impact on health of $\mathrm{A} 1$ gene}

Opioid peptides play a role in various biological processes, including respiration, analgesia, constipation and behavior in the humans [24]. BCM-7, opioid or narcotic as well as being an oxidant it is associated with milk intolerance and play a role in development of some human diseases such as human ischemic heart disease, diabetes mellitus, atherosclerosis, schizophrenia, autism, coronary heart disease, Autistic Spectral Disorder (ASD) and Sudden Infant Death Syndrome (SIDS) [21,13]. It may also be implicated in an additional range of auto-immune conditions. This protein is also linked to milk intolerance in some people [25]. Genetic polymorphism of bovine milk proteins has great interest in animal breeding, due to its relationships with milk production traits, milk composition and milk quality $[26,21]$.

Recent study finds that some large scale milk producing countries which are supplying milk as food throughout the world which is still insufficient to fulfill the public food requirement due to increasing of human population, as well as in bovine milk A1 beta- casein type of allele present which is proved that by drinking this type of bovine milk causing human health disease, these regions are need to improve more bovine milk production, dairy cattle breeding programs as well as dairy industries by reducing A1 betacasein, which will be search of an efficient way of the improvement of good milk production and the qualitative milk traits. For good milk production and reducing of $\mathrm{A} 1$ beta-casein gene in bovine need to analyze the status of beta-casein A1/A2 alleles in these animals to draw a sound breeding policy and minimize the risk of disseminating the A1 allele in Indian cattle. Selection and breeding of animals with desirable genotypes is of crucial importance for the genetic improvement of dairy cows. Study strongly recommend knowing the exact status of a cow in relation to its beta-casein genetic trait i.e. either it's A1, A2 or homozygous or heterozygous. Many researchers find the A1, A2 beta-casein polymorphism on Indigenous bovine population (Native, cross bred). Exotic cows, buffalos have revealed that $\mathrm{A} 1$ beta-casein is more frequent in exotic cattle while Indigenous dairy cattle and buffalo more frequent A2 beta-casein but A1 allele present in some bred. [21].

\section{Possible diseases}
a. Human ischemic heart disease
b. Diabetes mellitus
c. Atherosclerosis 


\section{d. Schizophrenia}

e. Autism

f. Coronary heart disease

g. Autistic spectral disorder (ASD) and

h. Sudden infant death syndrome (SIDS)

\section{Controversy on beta-casein A1 gene}

The controversy is that one group of scientists claim BCM a cause of many health problems in human whereas other groups report beneficial effects of BCM and declare both types of milk safe for children and adults. Two international Study Groups comprising of renowned scientists, one in New Zealand and the other by European Union (European Food Safety Authority), have gone through available publications and evidences on the subject and have concluded that fear about A1 milk was unfounded. There are also independent panel reports which have concluded that as yet there is no clinching evidence to ring public warning. The controversy in few developed countries appears to be driven by commercial motives as in New Zealand a company called A2 Corporation has been formed which owns A2 related patents and brand name and has been demanding mandatory testing of animals for purpose of labelling. Obviously, a small group of 'Activists' type of researchers is driving this controversy but unless concrete evidence emerges India should not fall prey to this propaganda [27].

\section{Conclusion}

Milk for human health ought to be drink. But, determination of milk quality and standards to A1 and A2 milk is also required. Therefore, more research have to be made. For accomplish, both also Government's and farmer's support has have to it.

Country related differences in the $\beta$-casein allele frequencies are observed which may be reflective of local breeding policies, some cross-breeding and most importantly targeted breeding for increased milk production traits. Some interesting trends arise from the data. The relative distribution of $\beta$-casein $\mathrm{A} 1$ and A2 alleles in Holstein and Friesian breeds appears to be region/ country specific with certain regions having a high level of $\beta$-casein $\mathrm{A} 1$, others having high level of $\mathrm{A} 2$ and others again having roughly similar allele frequency distributions for A1 and A2 [7].

Several surveys have shown that A1/A2 frequency is not breedspecific but area-specific. For example, in North America and North Europe A1 frequency in Holstein Friesen (HF) breed cow is very high (>90\%) but in German HF A2 frequency is high (97\%). In other countries A1 frequency in HF ranges between (40-65\%). In Guernsey breed from USA/Europe A2 frequency in cows and breeding bulls is very high (>98\%) almost equal to Indian breeds. In case of Jersey A2 gene frequency is higher (60-80\%) globally. Kerry breed from Ireland and Spotted breed from Hungary has A2 frequency above $75 \%$. In Indian hump breed cows A2 gene frequency is around $98 \%$ [27].

\section{References}

1. Tailford KA, Berry CL,Thomas AC, Campbell JH (2003) A casein variant in cow's milk is atherogenic. Atherosclerosis 170(1): 13-19.

2. Olenski K, Kamiński S, Szyda J, Cieslinska A (2010) Polymorphism of the beta-casein gene and its associations with breeding value for production traits of Holstein-Friesian bulls. Livestock Science 131(1): 137-140.

3. Konte M (1999) Le lait et les produits laitiers. Développement de systèmes de productions intensives en Afrique de l'ouest. Université de Nouakchott (RIM) Faculté des Sciences et Technologies des aliments: $2-25$.

4. Guetouache M, Guessas B, Medjekal S (2014) Composition and nutritional value of raw milk. Issues in Biological Sciences and Pharmaceutical Research 2(10): 115-122.

5. Fox PF, Uniacke-Lowe T, McSweeney PLHO, Mahony JA (2015). Dairy chemistry and biochemistry. Second Edition, Springer, Cham, ISBN 9783-319-14891-5.

6. Phadungath C (2005) Casein micelle structure: a concise review. Songklanakarin J Sci Technol 27(1): 201-212.

7. EFSA (2009) Review of the potential health impact of $\beta$-casomorphins and related peptides. EFSA Scientific Report 231: 1-107.

8. Walzem R, Dillard C, German JB (2002) Whey components: millennia of evolution create functionalities for mammalian nutrition: what we know and what we may be overlooking. Crit Rev Food Sci Nutr 42(4): 353-375.

9. Rahimi Z, Gholami M, Rahimi Z, Yari K (2015) Evaluation of beta-casein locus for detection of A1 and A2 alleles frequency using allele specific PCR in native cattle of Kermanshah, Iran. Biharean Biologist 9(2): 85-87.

10. Brunner J (1977) Milk proteins. Food proteins 175-208.

11. Sulimova G, Azari MA, Rostamzadeh J, Abadi MM, Lazebny 0 (2007) " $\kappa$-casein gene (CSN3) allelic polymorphism in Russian cattle breeds and its informative value as a genetic marker. Genetika 43(1): 88-95.

12. WalstraP, GeurtsT, Noomen A, Jellema A ,Van BoekelM, “JS (1999)” Dairy technology: Principles of milk properties and processes. CRC Press.

13. Rahman SM, Islam A, Alam MM, Hossain MM, Alim MA, et al. (2016) Analysis of Beta-casein gene variants of milk in cattle.

14. Kamiński S, Cieślińska A, Kostyra E, (2007) Polymorphism of bovine beta-casein and its potential effect on human health. J Appl Genet 48(3): 189-198.

15. SharmaV, Sharma N, Jawed B, Nautiyal SC, Singh R (2017) High Resolution Melt Curve Analysis for the detection of A1, A2 $\beta$-casein variants in Indian Cows. Journal of Microbiology and Biotechnology Research 3(1): 144-148.

16. Boro P, Naha BC, Saikia DP, Prakash C (2016) A1 and A2 Milk \& Its Impact on Human Health." International Journal of Science and Nature, 7(1):0105.

17. Elliott RB (1992) Epidemiology of diabetes in Polynesia \& New Zealand: In Epidemiology and Etiology of Insulin-Dependent Diabetes in the Young, eds Levy-Marchal C \& Czernichow P, Basel: Karger, Germany 21: 66-71.

18. Truswell A (2005) The A2 milk case: a critical review. European journal of clinical nutrition 59(5): 623-631.

19. Rangel AHN, Sales DC, Urbano SA, Galvao Junior JGB, Andrade Neto JC, et al. (2016) Lactose intolerance and cow's milk protein allergy. Food Sci Technol Campinas 36(2): 179-187.

20. Jinsmaa Y , Masaaki Y (1999) Enzymatic release of neocasomorphin and $\beta$-casomorphin from bovine $\beta$-casein. Peptides 20(8): 957-962.

21. Jaiswal KP, De S, Sarsavan A (2014) Review on bovine beta-casein $(\mathrm{A} 1, \mathrm{~A} 2)$ gene polymorphism and their potentially hazardous on human 
health. International Journal of Environment \& Animal Conservation $3(1): 1-12$.

22. Pasin G (2017) A2MilkFacts: What is A2 Milk? California Dairy Research Foundation, USA.

23. Sodhi M, Mukesh M, Kataria RS, Mishra BP, JoshiiB K (2012) Milk proteins and human health: A1/A2 milk hypothesis. Indian J Endocrinol Metab 16(5): 856.

24. Ng-Kwai-Hang K, Grosclaude F (2003) Genetic polymorphism of milk proteins. Advanced Dairy Chemistry-1 Proteins. Springer: 739-816.

25. Woodford K B (2008) A1 beta-casein, type 1 diabetes and links to other modern illnesses. IDF Congress.

26. Roginski H, Fuquay JW, Fox PF (2003) Encyclopedia of dairy sciences. 1-4: Academic press, USA.

27. Samed A (2016) A1-A2 beta casein milk: Is the controversy relevant to India? from a2-beta-casein-milk-is-the-controversy-relevant-to-india. (c) (1) $\begin{aligned} & \text { Creative Commons Attribution } 4.0 \\ & \text { International License }\end{aligned}$

For possible submissions Click Here Submit Article

\section{APDV $\quad$ Approaches in Poultry, Dairy \& Veterinary Sciences \\ Benefits of Publishing with us}

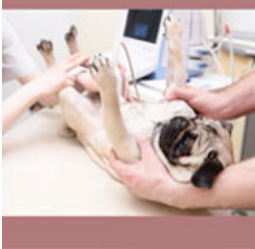

- High-level peer review and editorial services

- Freely accessible online immediately upon publication

- Authors retain the copyright to their work

- Licensing it under a Creative Commons license

- Visibility through different online platforms 